\title{
Stem cell markers expression evaluation in Oral Squamous Cell Carcinoma
}

\author{
Avaliação da expressão de marcadores de células-tronco no Carcinoma de Células Escamosas Oral \\ Evaluación de la expresión de marcadores de células madre en el Carcinoma de Células Escamosas \\ Oral
}

Received: 09/20/2021 | Reviewed: 09/30/2021 | Accept: 10/12/2021| Published: 10/14/2021

Julio Cesar Ramos Cadilho

ORCID: https://orcid.org/0000-0002-0897-2694

Universidade do Grande Rio, Brazil

E-mail: juliocrcadilho@gmail.com

Sílvia Maria De Carvalho Lyra

ORCID: https://orcid.org/0000-0002-7139-4698

Universidade do Grande Rio, Brazil

E-mail: silviamcarv@gmail.com

Ana Beatriz Machado Lima

ORCID: https://orcid.org/0000-0002-0581-5415

Universidade do Grande Rio, Brazil

E-mail: bbbiaml@gmail.com

Carina Maciel Silva-Boghossian

ORCID: https://orcid.org/0000-0002-4500-4350

Universidade do Grande Rio, Brazil

E-mail: carinabogho@yahoo.com.br

Claudia Maria Pereira

ORCID: https://orcid.org/0000-0003-1280-6055

Universidade do Grande Rio, Brazil

E-mail: claudia.pereira@unigranrio.edu.br

\begin{abstract}
Oral carcinogenesis is a highly complex process. Molecular studies demonstrate that some oral cancers progress from pre-neoplastic lesions. Cancer stem cells (CSCs), a small cellular group within the tumor, have currently received much attention by its self-renewal and tumor differentiation ability. It is considered that CSCs may be responsible for the relapse and metastasis of cancer. CSCs have been reported to express common embryonic stem cells markers such as Nestin and Nanog. The aim of the present study was to identify the presence of Nestin and Nanog markers in patients with oral squamous cell carcinoma (OSCC). Nine samples were collected from patients diagnosed with OSCC and two healthy oral mucosa were used as control. The markers expression in nine OSCC was determined by end-point PCR. The OSCC population analyzed was mostly composed of black and white males, with a mean age of 70.6 years, that reported alcohol and tobacco consumption. Nestin and Nanog stem cell markers were expressed in all OSCCs and normal samples analyzed. As these two markers have already been related to the mechanism of metastasis and relapses in cancer, its expression determination could help to understand the aggressive and invasive nature of OSCC.
\end{abstract}

Keywords: Oral squamous cell carcinoma; Stem cells; Nestin; Nanog.

\section{Resumo}

A carcinogênese oral é um processo altamente complexo. Estudos moleculares demonstram que alguns cânceres orais progridem a partir de lesões pré-neoplásicas. As células estaminais do cancro (Cscs), um grupo celular pequeno dentro do tumor, receberam atualmente muita atenção por sua capacidade auto replicante e da diferenciação do tumor. Considera-se que as Cscs podem ser responsáveis pela recidiva e metástase do câncer. Os Cscs foram relatados para expressar marcadores comuns das células estaminais embrionárias tais como Nestin e Nanog. O objetivo do presente estudo foi identificar a presença de marcadores de Nestin e Nanog em pacientes com carcinoma de células escamoso oral (CCEO). Foram coletadas nove amostras de pacientes diagnosticados com CCEO de boca e duas mucosas orais sadias foram utilizadas como controle. An expressão dos marcadores em nove CCEO foi determinada por PCR em tempo real. A população de CCEO analisada foi majoritariamente composta por homens negros e brancos, com idade média de 70,6 anos, que referiram consumo de álcool e tabaco. Marcadores de célulastronco de Nestin e Nanog foram expressos em todos os CCEO e amostras normais analisadas. Como esses dois marcadpres já foram relacionados ao mecanismo de metástase e recidivas no cancer, sua determinação de expressão poderia ajudar a entender a natureza agressiva e invasiva do CCEO.

Palavras-chave: Carcinoma espinocelular oral; Células-tronco; Nestin; Nanog. 


\begin{abstract}
Resumen
La carcinogénesis oral es un proceso muy complejo. Estudios moleculares demuestran que algunos cánceres orales progresan a partir de lesiones pre-neoplásicas. Las células madre cancerosas (CSCs), un pequeño grupo celular dentro del tumor, actualmente han recibido mucha atención por su capacidad de auto-renovación y diferenciación tumoral. Se considera que las CSCs pueden ser responsables de la recaída y metástasis del cáncer. Se ha informado de que las CSCs expresan marcadores comunes de células madre embrionarias como Nestin y Nanog. El objetivo del presente estudio fue identificar la presencia de marcadores de Nestin y Nanog en pacientes con carcinoma de células escamosas orales (OSCC). Se recogieron nueve muestras de pacientes con diagnóstico de OSCC y se utilizaron como control dos mucosas orales sanas. La expresión de los marcadores en nueve OSCC se determinó mediante PCR de punto final. La población OSCC analizada se componía principalmente de varones negros y blancos, con una edad media de 70,6 años, que reportaron consumo de alcohol y tabaco. Los marcadores de células madre Nestin y Nanog se expresaron en todos los OSCCs y muestras normales analizadas. Como estos dos marcadores ya se han relacionado con el mecanismo de metástasis y recaídas en el cáncer, su determinación de la expresión podría ayudar a entender la naturaleza agresiva e invasiva de OSCC.
\end{abstract}

Palabras clave: Carcinoma de células escamosas orales; Células madre; Nestin; Nanog.

\title{
1. Introduction
}

Oral squamous cell carcinoma (OSCC) is the most frequent type of the head and neck tumors (Mehanna et al., 2010). Late diagnosis is related to poor prognosis, and it still presents high mortality levels, despite the improvements on therapy (Mulhall et al., 2011; Silva et al., 2012). Chronic exposition to environment carcinogens, as alcohol and tobacco can lead to genetic, epigenetic, and metabolic alterations (Lippman et al, 2005).

Stem cells are implicated in the origin of cancer. These cells can acquire mutations and epigenetic changes that can favor the progression to malignancy (Celetti et al., 2012). Many solid malignancies, including the OSCC, contain a small population of tumorigenic stem cells. Cancer Stem Cells (CSCs) or Tumor Stem Cells (TSCs) originate from the epithelial lining of the oral cavity. Normal basal stem cells are considered as starting points for malignant transformation in oral carcinogenesis and the keys to the genetic, phenotypic, and physiological alterations (Owens \& Watt, 2003). CSCs are defined as a small fraction of cells within the tumor that can self-renewal, differentiation and tumorigenicity (Clevers, 2011), supposed to be involved in cancer recurrence and metastasis. Other important aspect of CSCs is the resistance to cytotoxic chemotherapy and radiation (Dean, 2005), which has important clinical implications.

Ideal markers of CSCs should disclose all acquired signs of self-sufficiency in growth, anchorage independent growth, apoptosis or drug resistance, invasion, metastatic potential, beside self-renewal ability conferred by the cell of its origin, the normal stem cells. In a well-differentiated tumor tissue, suprabasal cells present a basal phenotype distinct from highly keratinized superficial cells (Kaur \& Li, 2000); Evander et al., 1997). Liu et al. (Liu \& Brown, 2010) demonstrated a hyperexpression of the CSC's markers CD133, CD44 and Nestin in anaplastic thyroid carcinoma (ATC). Nanog, another marker of CSCs, was related to the formation of SCC, from warts in mice. It was showed that Nanog was able to induce the expression of Zeb1, Zeb2, Twist1, Prrx1, genes associated to epithelial mesenchymal transition (EMT) phenotype and miR-21 (Palla et al., 2015). Nanog is a protein that contains a homeodomain. It maintains the pluripotency of mouse embryonic stem cells (ESCs), inhibiting NFkB and cooperating with STAT3 (Mitsui et al., 2003). The Nestin intermediate filament protein, initially considered as a marker of neural stem cells, is abundant in progenitor cells derived from ESCs that have the potential to develop in multiple strains. (Wiese et al., 2004). Since the CSCs are implicated in the origin of cancer, and they are involved in recurrence, metastasis and resistance to therapy, this study aimed to analyze the expression of the stem cells markers in OSCC. We observed the expression of Nestin and Nanog in OSCC and normal oral mucosa samples by conventional PCR method. 


\section{Materials and Methods}

Nine primary OSCC samples were obtained in the Stomatology Center of the Universidade do Grande Rio (Unigranrio). All samples were collected and divided in two specimens: one specimen was stored in $10 \%$ formalin solution for histopathological diagnosis by two pathologists of Universidade Federal Fluminense (UFF); the other specimen was stored at $80^{\circ} \mathrm{C}$, in a cryotube containing RNA Later for posterior molecular analysis. To control group, two normal oral samples were obtained from prosthetic surgeries from the Periodontics Clinic of Unigranrio. Research protocols were approved by the Ethics Committee of Unigranrio (protocol number 1.753.632). Informed consent was obtained from all patients.

\subsection{RNA isolation and conventional PCR}

Total RNA was isolated from the cells using Trizol reagent (Thermo fisher Scientific, Waltan, MA, USA), following the manufacturer's instructions. The material was lysed in $800 \mu \mathrm{l}$ of Trizol and then incubated with $1.0 \mu \mathrm{l}$ of glycogen for 5 min at room temperature. After that, it was added $160 \mu \mathrm{l}$ of chloroform and centrifugation was performed for 5 min to separate the phases. The upper phase was transferred to a new tube and the RNAs were precipitated by the addition of 0.7 volumes of frozen isopropanol, with incubation at $-20^{\circ} \mathrm{C}$ overnight. The samples were then centrifuged for $30 \mathrm{~min}$ at $4^{\circ} \mathrm{C}$. The dry pellet was dissolved in $15 \mu 1$ of RNAse free water. Total RNA obtained was quantified in the Denovix DS-11 (Wilmington, DE, USA) spectrophotometer.

\subsection{Preparation of cDNA for analysis by conventional PCR}

For cDNA synthesis, $2.0 \mu \mathrm{g}$ of total RNA were submitted to Reverse transcription PCR (RT-PCR) using the enzyme SuperScript III (Thermo Fisher Scientific, Waltan, MA, USA), according to the manufacturer's instructions. The final RTPCR products were diluted 10X by the addition of $180 \mu \mathrm{l}$ of RNAse free water. The cDNA quality was evaluated by PCR amplification of a fragment of the $\beta$-actin gene (ACTB - NM 001101).

To evaluate the presence of CSCs markers in OSCC, two set of primers were used to evaluate the expression of Nestin or Nanog previously designed and standardized by our group. The primer sequences and melting temperatures are available in Table 1. cDNAs from two glioblastomas cell lines (GBM11 and T98G) were used as positive controls to PCR reaction. For PCR reaction were used, $2 \mu \mathrm{l}$ of cDNA, $2.5 \mu \mathrm{l}$ of 10X buffer; $2 \mu \mathrm{l}$ of $\mathrm{MgCl}_{2}(50 \mathrm{mM}) ; 0.5 \mu \mathrm{l}$ of dNTPs $(10 \mathrm{mM})$; $10 \mathrm{pmol}$ of each primer and $1.25 \mathrm{U}$ of Uni-Taq DNA Polymerase in a final reaction volume of $251 \mu$, and the following amplification conditions: initial denaturation for $2 \mathrm{~min}$ at $95^{\circ} \mathrm{C} ; 35$ cycles at $95^{\circ} \mathrm{C}$ for $30 \mathrm{~s}$; annealing for $45 \mathrm{~s}$ according to the temperature of each primer standardization, and then, $72^{\circ} \mathrm{C}$ for $45 \mathrm{~s}$, with a final elongation phase at $72^{\circ} \mathrm{C}$ for $7 \mathrm{~min}$. The fragments were visualized by electrophoresis in $1.5 \%$ agarose gel stained by Red ${ }^{\mathrm{TM}}$ Gel (Biotium, Hayward, CA, USA) in order to evaluate the integrity of the samples.

\section{Results}

\subsection{Clinical pathological characteristics of OSCC patients}

Demographic and clinicopathological characteristics of the nine OSCCs patients analyzed showed that this group was composed mostly by males $(77.8 \%)$, whites $(55.6 \%)$, over 60 years $(88.9 \%)$, smokers $(88.9 \%)$ and drinkers $(55.6 \%)$. The most common anatomic site affected by OSCC was the floor of mouth (44.5\%) followed by the lateral border of the tongue (33.3\%). Histological grade revealed that $66,7 \%$ of the OSCC samples were moderately differentiated. 


\subsection{Evaluation of presence of Nestin and Nanog in OSCC samples}

The PCR results demonstrated that the nine OSCC and the two healthy oral mucosa samples (N5 and N25), including the two PCR controls (the GBMs cell lines - GBM11 and T98G) expressed the stem cell marker Nestin (Figure 1A and 1B).

Figure 1: Analysis of Nestin expression In Oral squamous cell carcinoma (OSCC). A - Nestin expression in OSCC samples, control glioblastoma strains (GBM11 and T98G) and healthy oral mucosa samples (N5 and N25); B - Nestin expression in OSCC samples and GBM11; L: Ladder (100 PB-100 base pairs); C- negative control.
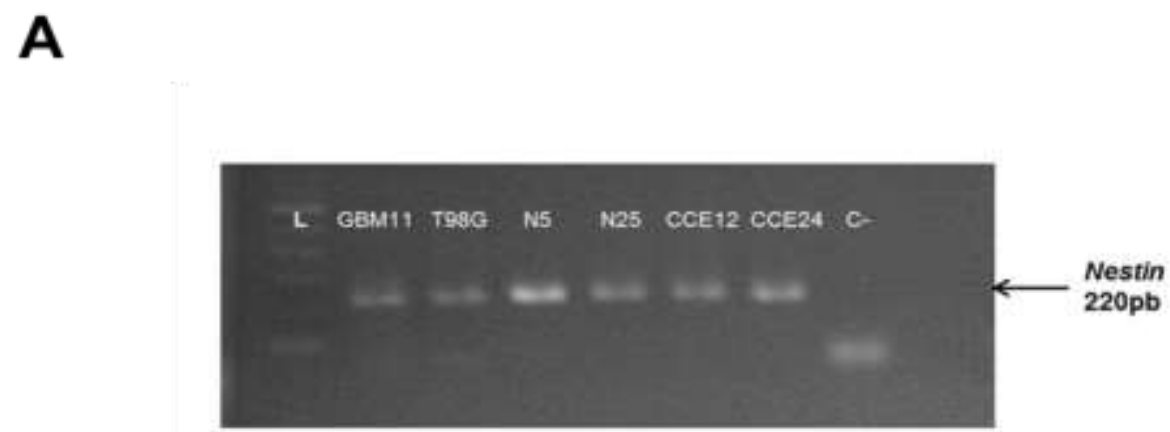

B

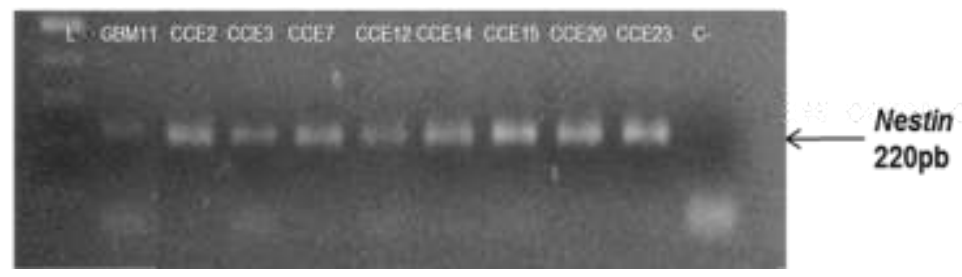

Fonte: Laboratório de Genética UNIGRANRIO(LABGEN).

A very similar pattern of expression was observed in relation to Nanog in all samples analyzed (Figure 2A and 2B). Due to the small number of samples, it was not possible to associate the expression of the markers with the clinical and pathological data of the OSCC patients. 
Figure 2: Nanog expression analysis in Oral squamous cell carcinoma (OSCC). A- Nanog expression in OSCC samples, strains of glioblastoma (GBM) (GBM11 and T98G) and samples of healthy oral mucosa (N5 and N25); B- Nanog expression in OSCC samples and GBM strains. L: Ladder (100 base repairs); C- negative reaction control.

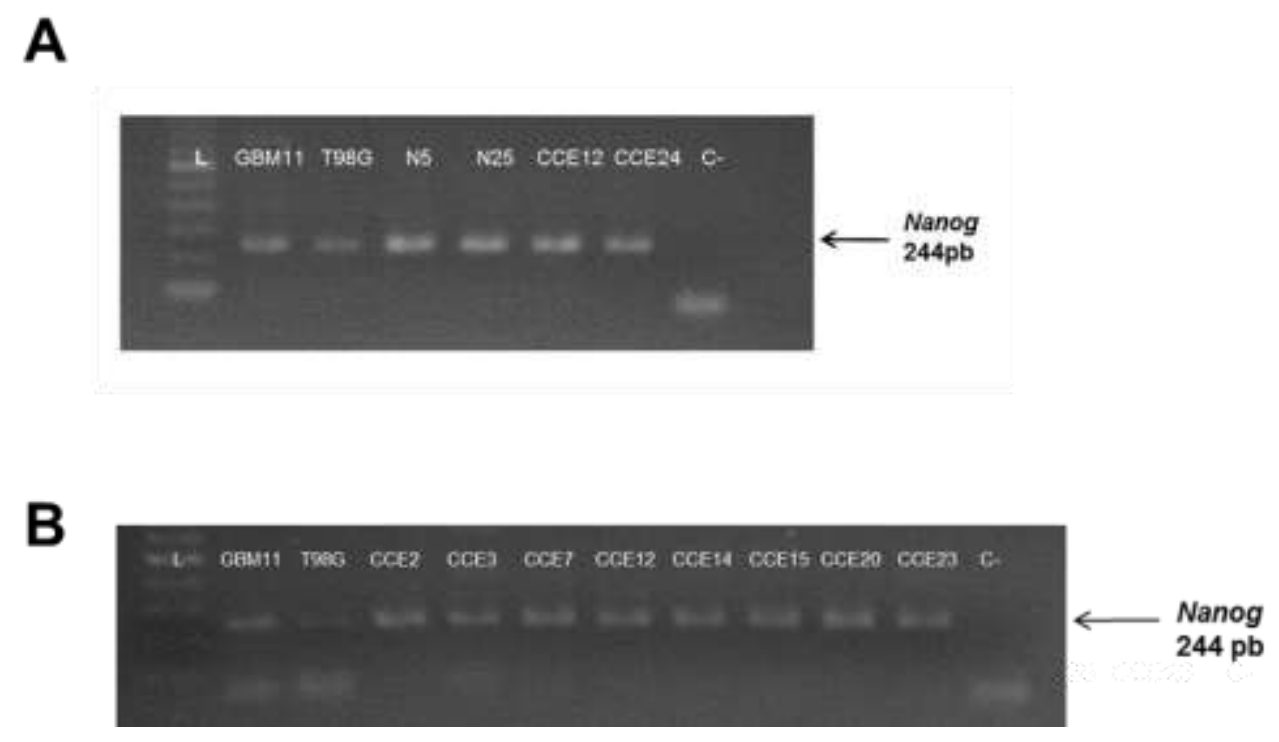

Fonte: Laboratório de Genética UNIGRANRIO(LABGEN).

\section{Discussion}

The main objective of this study was to identify the presence of stem cells in the OSCC by the analysis mRNA expression of Nestin and Nanog using conventional PCR method. We demonstrated the presence of two CSC cell markers Nanog and Nestin in nine OSCC and two oral healthy mucosa. Tumor-like cancer cells or tumor initiating cells originate from the epithelial lining of the oral cavity. Normal basal stem cells are considered the key to changes in their genotype, phenotype and physiology, and the starting point for malignant transformation in oral carcinogenesis (6). The concept of stem cell hierarchy in cancer, coupled with the EMT process, seems to explain the biology of most cancers, as well as the failure of currently used therapeutic methods. LIU et al. (Liu \& Brown, 2010) demonstrated a hyperexpression of Nestin in anaplastic thyroid carcinoma (ATC). Nanog was related to the formation of SCC in mice (Palla et al., 2015). The Nanog protein maintains the pluripotency of mouse ESCs (Mitsui et al., 2003), and the Nestin intermediate filament protein is abundant in progenitor cells derived from ESCs (Wiese et al., 2004). Besides that, the positive regulation of these proteins has been closely associated with tumor metastases and a poor prognosis in various human malignancies, including prostate cancer, lung adenocarcinoma, gliomas, rectal cancer and OSCC (Chiou et al., 2008; Chioubet al., 2010)

In this present study the molecular markers Nestin and Nanog was identified in the nine samples of OSCC studied. CHIOU et al. (Chiou et al., 2008) demonstrated Nestin and Nanog expression in OSCC's oncospheres. In the same study they showed a correlation between high expression of Nanog and advanced tumor staging in 52 patients (Chiou et al., 2008). Nanog and Nestin expression have already been associated to chemotherapy resistance in head and neck squamous cell carcinomas (HNSCCs) (Facompre et al., 2012). Another relevant data is that Nanog have an important role in the in the development of EMT phenotype in SCC, an essential event for dissemination and metastasis of this cancer (Palla et al., 2015).

Healthy oral mucosa samples also exhibited expression of Nestin and Nanog markers, in accordance with the literature (Dong et al., 2010; Marynka-Kalmani et al., 2010; Smane-Filipova et al. 2016). The expression of Nestin has already been described in the lamina propria of the rat's oral mucosa (Dong et al., 2010). It was also observed the presence of 
moderate and elevated levels of Nestin protein in the oral mucosa of individuals with cleft lip and palate (Smane-Filipova et al. 2016). These results suggest that the basal stem cells of the lamina propria of the normal oral mucosa have a distinct population of stem cells like those derived from the neural crest, with the ability to give rise to different cellular types. Normal basal stem cells are considered as possible starting points for malignant transformation in oral carcinogenesis (Owens \& Watt, 2003).

The preliminary results of this present study showed the presence of Nestin and Nanog in nine OSCC samples analyzed. These molecules play an important role in the EMT phenotype, and the identification of these two markers is fundamental to the comprehension about the OSCC biology. However, is necessary to clarify that the evaluation only of Nestin and Nanog expression is not enough for the characterization of a CSC population in OSCC samples. Future analyzes that contemplate the evaluation of a greater number of CSC markers in a larger number of samples. The comparison of these markers with the clinicopathological data of OSCC patients should be conducted to determinate the influence of the CSC markers in prognostic and survival of these patients.

\section{Conclusion}

In this preliminary study, we observed the expression of Nestin and Nanog in OSCC samples. These are important molecular markers involved in the metastasis and dissemination process in malignant neoplasias. Nestin and Nanog were also observed in normal oral epithelium samples, probably suggesting the existence of a population of stem cells with the ability to originate different types of tissues. However, is important to mention that is necessary to evaluate other CSC markers, in addition to Nestin and Nanog in a larger number of samples, for the correct characterization of a population of CSCs in OSCC and oral mucosa.

\section{Acknowledgments}

This study was supported by Fundação de Amparo à Pesquisa do Estado do Rio de Janeiro (FAPERJ) (E_34/2014) and Fundação Nacional de Desenvolvimento de Ensino Superior Privado (FUNADESP) (5100953). We thank Andressa Raquel Alves Pinheiro, Prof. Luiz Carlos Moreira,Prof. Vânia do Carmo Rodrigues from Unigranrio for the contribution with the acquisition of the samples and Prof. Simone de Queiroz Chaves Lourenço from Universidade Federal Fluminense for histopathological analyses.

\section{Conflict of interest}

The authors declare no conflicts of interest in this study.

\section{References}

Celetti, A., Merolla, F., Luise, C., Siano, M., Staibano, S. (2012) Novel Markers for Diagnosis and Prognosis of Oral Intraepithelial Neoplasia. INTECH Open Access Publisher.

Clevers, H. (2011) The cancer stem cell: premises, promises and challenges. Nat Med.; 17(3): 313-9.

Chiou, S. H., Yu, C. C., Huang, C. Y., Lin, S. C., Liu, C. J., Tsai, T. H., Chou, S. H., Chien, C. S., Ku, H. H., Lo, J. F. (2008) Positive correlations of OCT4 and Nanog in oral cancer stem-like cells and high-grade oral squamous cell carcinoma. Clin Cancer Res.; 14(13): 4085-95.

Chiou, S. H., Wang, M. L., Chou, Y. T., Chen, C. J., Hong, C. F., Hsieh, W. J., Chang, H. T., Chen, Y. S., Lin, T. W., Hsu, H. S., Wu, C. W. (2010) Coexpression of Oct4 and Nanog enhances malignancy in lung adenocarcinoma by inducing cancer stem cell-like properties and epithelial-mesenchymal transdifferentiation. Cancer Res.; 70(24): 10433-44.

Silva, S. D., Hier, M., Mlynarek, A., Kowalski, L. P., Alaoui-Jamali, M. A. (2012) Recurrent oral cancer: current and emerging therapeutic approaches. Front Pharmacol.; 3: 1-7. 
Dean, M., Fojo, T., Bates, S. (2005) Tumour stem cells and drug resistance. Nat Rev Cancer.; 5(4): 275-84.

Dong, R., Liu, X., Fan, M., Yang, L., Peng, L., Zhang, L. (2010) Isolation and differentiation of nestin positive cells from rat oral mucosal lamina propria. Differentiation.; 79(1): 9-14.

Evander, M., Frazer, I. H., Payne, E., Qi, Y. M., Hengst, K., McMillan, N. A. (1997) Identification of the alpha6 integrin as a candidate receptor for papillomaviruses. J Virol.; 71(3): 2449-56.

Facompre, N., Nakagawa, H., Herlyn, M., Basu, D. (2012) Stem-like cells and therapy resistance in squamous cell carcinomas. Adv Pharmacol.; 65: 235-65.

Kaur, P., Li, A. (2000) Adhesive properties of human basal epidermal cells: an analysis of keratinocyte stem cells, transit amplifying cells, and postmitotic differentiating cells. J Invest Dermatol.; 114(3): 413-20.

Lippman, S. M, Sudbø, J., Hong, W. K. (2005). Oral cancer prevention and the evolution of molecular-targeted drug development. Oral cancer prevention and the evolution of molecular-targeted drug development. J Clin Oncol.; 23(2): 346-56.

Marynka-Kalmani, K., Treves, S., Yafee, M., Rachima, H., Gafni, Y., Cohen, M. A., Pitaru, S. (2010) The lamina propria of adult human oral mucosa harbors a novel stem cell population. Stem Cells.; 28(5): 984-95.

Mehanna, H., Paleri, V., West, C. M., Nutting, C. (2010) Head and neck cancer-Part 1: Epidemiology, presentation, and prevention. BMJ.; 341 : 4684.

Mitsui, K., Tokuzawa, Y., Itoh, H., Segawa, K., Murakami, M., Takahashi, K., Maruyama, M., Maeda, M., Yamanaka, S. (2003) The homeoprotein Nanog is required for maintenance of pluripotency in mouse epiblast and ES cells. Cell.; 113(5): 631-42.

Mulhall, H. J., Labeed, F. H., Kazmi, B., Costea, D. E., Hughes, M. P., Lewis, M. P. (2011) Cancer, pre-cancer and normal oral cells distinguished by dielectrophoresis. Anal Bioanal Chem.; 401(8): 2455-63.

Owens, D. M., Watt, F. M. (2003) Contribution of stem cells and differentiated cells to epidermal tumours. Nat Rev Cancer.; 3(6): 444-51.

Palla, A. R., Piazzolla, D., Alcazar, N., Cañamero, M., Graña, O., Gómez-López, G., Dominguez, O., Dueñas, M., Paramio, J. M., Serrano, M. (2015) The pluripotency factor NANOG promotes the formation of squamous cell carcinomas. Sci Rep.; 5: 10205.

Smane-Filipova, L., Pilmane, M., Akota I. (2016) Immunohistochemical analysis of nestin, CD34 and TGF 33 in facial tissue of children with complete unilateral and bilateral cleft lip and palate. Stomatologija.; 18(3): 98-104.

Wiese, C., Rolletschek, A., Kania, G., Blyszczuk, P., Tarasov, K. V., Tarasova, Y., Wersto, R. P., Boheler, K. R., Wobus, A. M. (2004) Nestin expression--a property of multi-lineage progenitor cells? Cell Mol Life Sci.; 61(19-20): 2510-22. 